\title{
Analisa Perpindahan Panas dan Pengembunan pada Pengembunan Uap Cair dengan Pengembunan Parsial Bertingkat
}

\author{
Martomo Setyawan ${ }^{1, *}$, Maryudi $^{1}$ \\ Program Studi Teknik Kimia, Universitas Ahmad Dahlan, Jl. Prof. Dr. Soepomo, SH., Janturan, Warungboto \\ Yogyakarta, 55164 \\ *email:martomo@che.uad.ac.id
}

\begin{abstract}
Production of charcoal as an alternative fuel have been growth as the solution of the national problem about decreasing energy source from petroleum. Production of charcoal has a useful side product in the form of liquid smoke. The liquid smoke can be used as food preservative in the high grade of liquid smoke and the low grade liquid smoke can be used as wood preservative form termite. The conventional process on production liquid smoke it was using redistillation the raw liquid smoke from direct condensation. This process was consumed lot of energy. Liquid smoke consist of some components which had different boiling point.

The aim of this research was to study the influence in using different combination of vertical condensor at the condensation of liquid smoke process fro the making coconut shell charcoal. This research was done by make some coconut shell charcoal and the smoke which was formed was flown passed some condensors.

The result of this research shown that condensation of liquid smoke in the vertical condenser occured a contact between condensation down flow and the vapour. The temperature of the condensation taking point can be adjust by adjusting heat transfer area of the vertical condenser. The tar can be taken at the temperature above $100^{\circ} \mathrm{C}$. The colour of the liquid smoke was lighter with the lower temperature.
\end{abstract}

Keywords: liquid smoke, vertical condensor, configuration of condensor

\section{Pendahuluan}

Salah satu sumber energi alternatif yang dapat dikembangkan adalah pemanfaatan biomassa yang merupakan limbah dari berbagai macam industri. Salah satu potensi yang cukup besar adalah limbah padatan yang berasal dari industri berbasis kelapa berupa tempurung kelapa yang jumlahnya melimpah di Indonesia. Pembuatan arang tempurung kelapa sebagai bahan bakar alternatif sudah banyak dikembangkan dan menjadi industri skala mikro. Pembuatan arang menghasilkan limbah berupa asap hasil pembakaran. Dampak asap yang terlepas ke udara dapat berdampak luas berupa polusi udara yang berakibat pada gangguan kesehatan manusia, berupa iritasi saluran pernafasan yang menyebabkan rasa tidak enak di saluran pernafasan dan dapat diikuti infeksi. Asap hasil pembakaran arang tempurung kelapa mengandung senyawa-senyawa yang dapat dimanfaatkan untuk berbagai keperluan. Untuk dapat memanfaatkan senyawa hasil pembakaran tempurung kelapa maka asap tersebut harus diembunkan sehingga terbentuk asap cair. Pemanfaatan asap cair antara lain untuk pengawet makanan karena asap cair dapat menghambat pertumbuhan bakteri dan aman sebagai pengawet alami. Asap cair dapat juga digunakan untuk bahan anti rayap dalam industri kayu [1].

Pengembunan asap menjadi asap cair sebagai merupakan nilai lebih dari industri pembuatan arang, selama ini teknologi yang berkembang adalah pengambilan asap dengan diembunkan dengan pengembun total, selanjutnya embunan yang dihasilkan diuapkan ulang pada suhu antara $100-120{ }^{\circ} \mathrm{C}$ dan diembunkan kembali. Penelitian oleh beberapa peneliti di UAD telah meneliti proses pembuatan arang tempurung kelapa yang terintegrasi dengan pengembunan asap cair dalam skala laboratorium [2]. Proses pengambilan asap cair yang telah dilakukan adalah dengan mengembunkan asap cair kemudian didistilasi ulang, proses ini memerlukan waktu yang lama dan energi yang besar. Pada penelitian ini diajukan proses pengambilan asap cair yang lebih cepat dan hemat energi yaitu dengan mengembunkan asap secara parsial dengan beberapa pengembun yang disusun secara seri. Pengembun parsial dirancang tercapai kondisi setimbang uap-cair. Pengembunan parsial akan mengembunkan sebagian komponen asap dan meneruskan sebagian gas yang ada, dengan mengatur suhu pada setiap pengembun parsial maka dapat diembunkan komponen asap cair dengan titik didih tertentu.

Pengambilan asap cair dari pengarangan tempurung kelapa dengan kondensasi total dilanjutkan redistilasi memerlukan waktu panjang dan energi yang banyak, perlu dilakukan inovasi untuk mempercepat proses dengan pengembunan parsial secara seri, dengan cara ini tidak diperlukan energi untuk menguapkan kembali pada proses redistilasi. 
Asap cair diproduksi dengan pengembunan bertingkat, pada suhu $300-450{ }^{\circ} \mathrm{C}$ asap hasil pembakaran tempurung kelapa keluar dari dapur dan didinginkan sampai suhu $150-200{ }^{\circ} \mathrm{C}$ maka tar yang pekat akan mengembun dan selanjutnya didinginkan sampai 80 dan $120{ }^{\circ} \mathrm{C}$ maka tar yang lebih ringan akan mengembun, selanjutnya asap cair jernih didinginkan sampai suhu $30{ }^{\circ} \mathrm{C}[3]$.

Proses pengembunan terjadi ketika suatu uap berada dalam kondisi jenuh dan diambil panasnya. Uap yang berada dalam kondisi lewat panas atau suhunya diatas suhu jenuhnya untuk dapat menjadi cair maka harus didinginkan sampai keadaan jenuh, selanjutnya setelah sampai kondisi jenuh panas yang diambil digunakan untuk mengubah fase uap menjadi fase cair. Selanjutnya setelah menjadi cair panas yang diambil digunakan untuk menurunkan suhu cairannya.

Proses pengembunan terjadi karena proses perpindahan panas dari fase uap menuju fase cair. Perpindahan panas dari fase uap ke fase cair melalui berbagai macam tahapan yaitu:

1. Perpindahan panas dari uap ke logam kondensor melalui tahanan film dengan mekanisme konveksi, dengan rumus

$\mathrm{q}=\mathrm{h}_{\mathrm{as}} . A\left(\mathrm{~T}_{\text {logam }}-\mathrm{T}_{\text {uap }}\right)$

2. Perpindahan panas melalui logam kondensor dengan mekanisme konduksi, dengan persamaan

$\mathrm{q}=\mathrm{k}$. A. $\mathrm{x} \cdot\left(\mathrm{T}_{\text {logam dalam }}-\mathrm{T}_{\text {logam luar }}\right)$

3. Perpindahan panas dari logam menuju udara melalui tahanan film dengan mekanisme konveksi, dengan persamaan

$\mathrm{q}=\mathrm{h}_{\text {air. }} \cdot \mathrm{A}\left(\mathrm{T}_{\text {udara }}-\mathrm{T}_{\text {logam }}\right)$

Ketiga mekanisme diatas berjalan secara seri sehingga persamaan dapat digabung

$\mathrm{Q}=\mathrm{U} . A .\left(\mathrm{T}_{\text {udara }}-\mathrm{T}_{\text {uap }}\right)$

$$
\frac{1}{U}=\frac{1}{h_{a s}}+\frac{x}{k}+\frac{1}{h_{u d a r a}}
$$

Koefisien Perpindahan keseluruhan (U) dipengaruhi koefisien konveksi uap-logam ( $\mathrm{h}_{\mathrm{as}}$ ), koefisien konduksi logam $(\mathrm{k})$ dan koefisien konveksi logam udara $\left(\mathrm{h}_{\mathrm{udara}}\right)$. Koefisien perpindahan panas konveksi dipengaruhi oleh kecepatan aliran fluida.

Proses pengembunan dengan pengembun vertikal maka kemampuan pengembunan alat pengembun tergantung dari panjang alat pengembun [4].

\section{Metode Penelitian}

Penelitian dilakukan dengan mengarangkan sejumlah $3 \mathrm{~kg}$ tempurung kelapa dan selanjutnya asap yang terbentuk diembunkan melalui 2 buah pengembun tegak dengan variasi luas permukaan, gambar alat percobaan dapat dilihat pada gambar dibawah ini

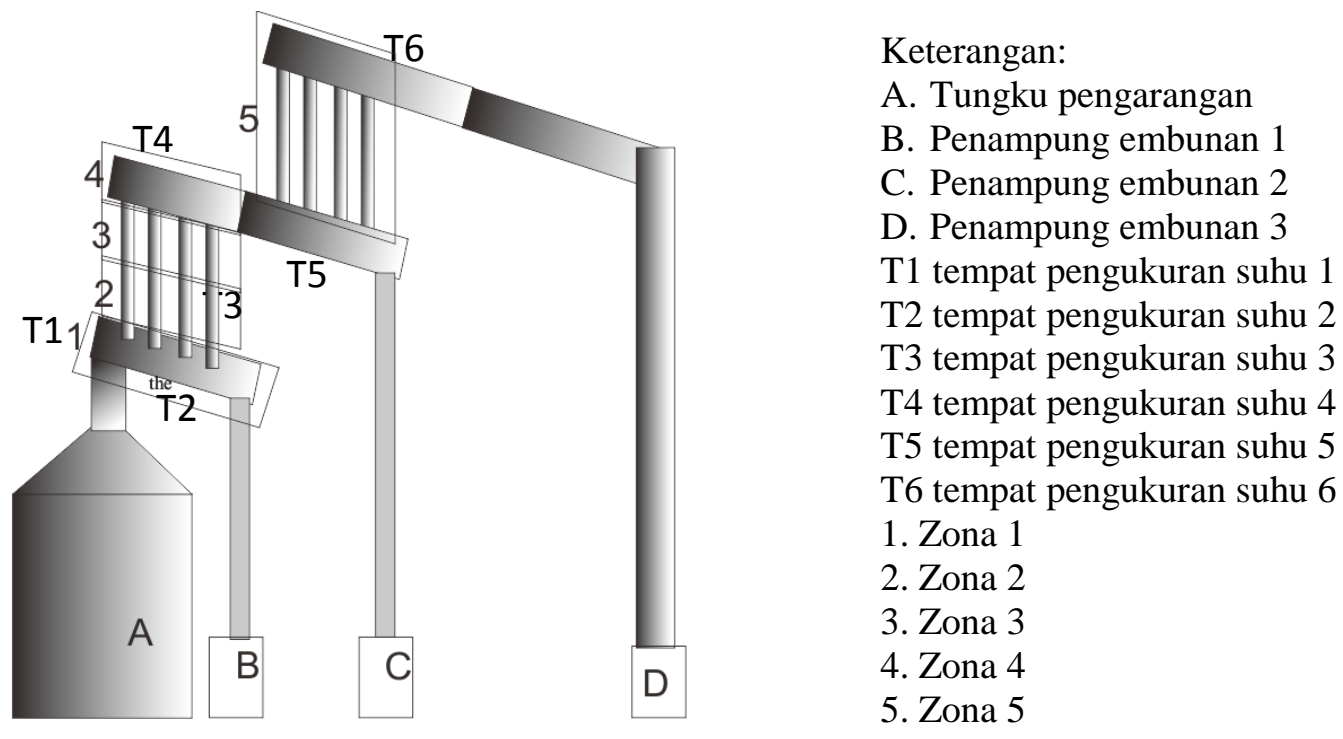

Gambar 1. Alat pengembun asap cair 
Variasi luas permukaan dilakukan di zona pengembun 2, 3, dan pengembun 5 dan hasil embunannya ditampung di penampung embunan $\mathrm{B}$ untuk zona pengembun $1,2,3$, pada penampung embunan $\mathrm{C}$ untuk pengembun 4 dan 5 dan sisa uap diembunkan pada penampung pengembun D. Sedangkan pengukuran suhu dilakukan pada T1 sampai T7

\section{Hasil Penelitian dan Pembahasan}

Percobaan untuk mengetahui perpindahan panas yang terjadi selama proses pengembunan dilakukan dengan mengukur suhu pada 6 posisi seperti tergambar dalam alat percobaan. Dari percobaan perubahan suhu tiap dapat dilakukan analisa perpindahan panas tiap zone pengembun, adapun data percobaan dapat dilihat pada gambar berikut:

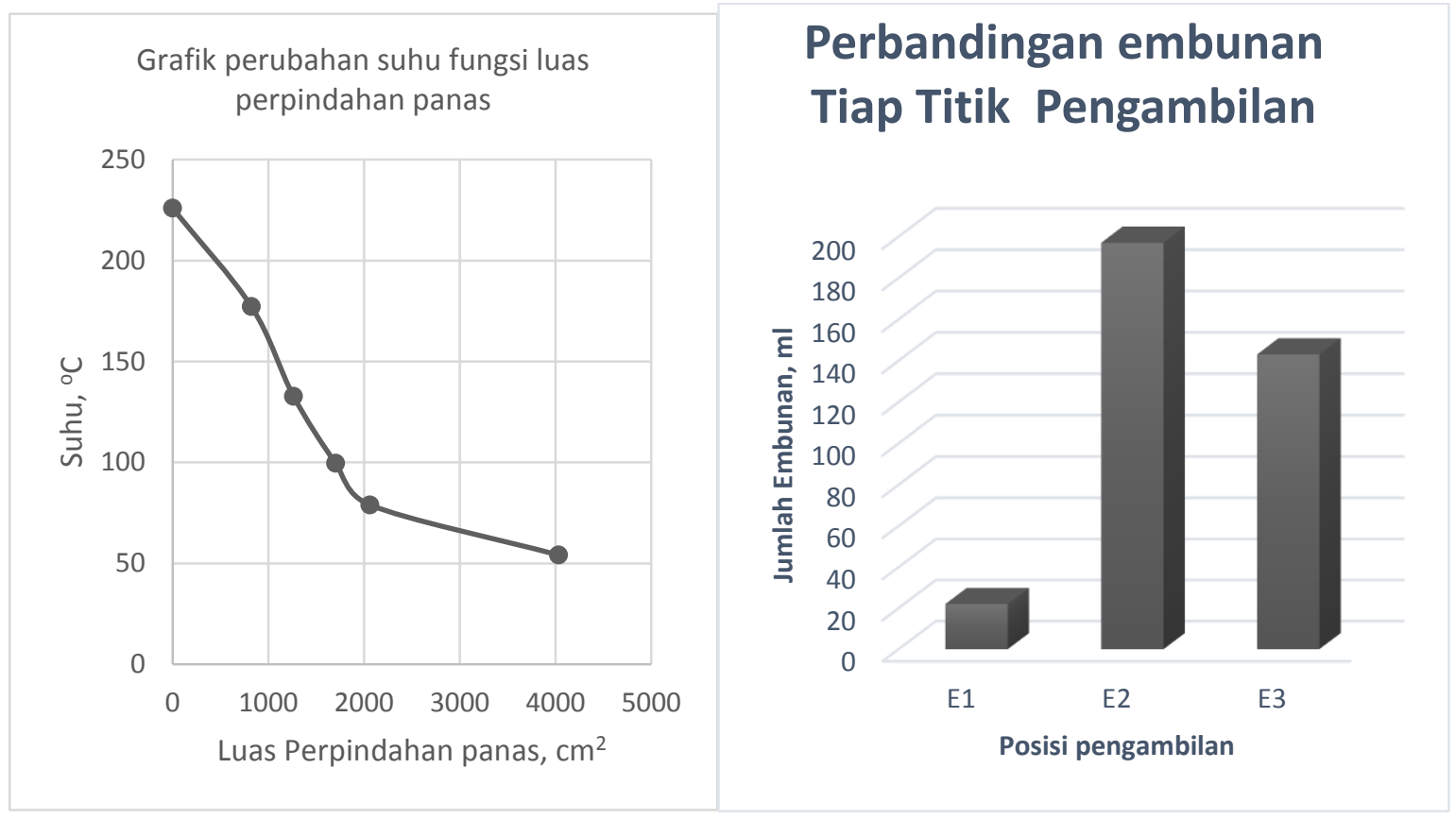

Gambar 2. Perubahan suhu Fungsi Luas Perpindah: panas

Gambar 3. Jumlah Embunan tiap Posisi

Dari gambar diatas serangkaian alat pengembun dibagi menjadi 5 zone, zona pertama berupa pipa dengan diamater $5,7 \mathrm{~cm}$ dengan panjang $46 \mathrm{~cm}$ sehingga memiliki luas area $823,73 \mathrm{~cm}^{2}$, zona 2 berupa pengembun tegak seluas $439,82 \mathrm{~cm}^{2}$, zona 3 kelanjutan zona 2 dengan luas sama dengan zona 2, zona 4 berupa pipa penghubung miring dari zona 3 ke zona 5 dengan luas perpindahan panas $358,14 \mathrm{~cm}^{2}$ dan zona 5 adalah pengembun tegak dengan luas perpindahan panas $1969,78 \mathrm{~cm}^{2}$

Zona 1 pada zona ini embunan akan mengalir searah dengan asap sehingga tidak terjadi kontak uap cair dengan baik karena selain aliran searah diamater pipa besar sehingga kontak uap dan embunan sedikit. Pada zona ini terjadi penurunan suhu sebesar $48,7{ }^{\circ} \mathrm{C}$. Pada zona ini terjadi gradien suhu arah radial yang besar [5] sehingga asap yang mengembun adalah asap yang bersentuhan dengan dinding sedangkan yang tidak bersentuhan dengan dinding suhu masih tinggi. Hasil embunan pada zona ini campuran antara tar dan komponen yang bertitik embun rendah [5]. Kisaran suhu pada pengembun ini $226{ }^{\circ} \mathrm{C}$ sampai dengan $177{ }^{\circ} \mathrm{C}$.

Zona 2 pada zona pengembun tegak maka embunan yang terbentuk sepanjang pipa akan mengalir kebawah sehingga terjadi kontak antara embunan yang mengembun diatas dengan suhu yang lebih rendah, dengan adanya kontak antara asap dengan suhu relatif tinggi dengan embunan yang relatif rendah, maka komponen dengan titik embun rendah akan menguap kembali dan akan mengembun pada fase pengembun dengan suhu yang lebih rendah. Pada zona ini diperoleh embunan berupa tar yang kental tidak ada komponen dengan titik embun yang rendah. Dengan pengembun tegak terjadi keseimbangan uap cair sehingga yang mengembun adalah komponen yang memliki kisaran titik embun tertentu. Kisaran titik embun pada zona ini adalah $177{ }^{\circ} \mathrm{C}$ sampai $133{ }^{\circ} \mathrm{C}$. Pada zona ini dengan luas perpindahan panas $439,82 \mathrm{~cm}^{2}$ dapat menurunkan suhu $44{ }^{\circ} \mathrm{C}$.

Zona pengembunan 3 merupakan kelanjutan zona 2, pada zona 3 kisaran suhu antara 133 sampai 100. Dibandingkan dengan zona 2 maka di zona 3 penurunan suhu lebih kecil yaitu $44{ }^{\circ} \mathrm{C}$ pada zona 2 dan $33{ }^{\circ} \mathrm{C}$ 
pada zona 3 hal ini disebabkan karena di zona 2 panas yang diambil oleh udara lebih banyak panas sensibel untuk menurunkan suhu asap disamping panas untuk pengembunan, karena di dalam pipa pengembun terjadi kontak embunan dan asap, sedangkan pada zona 3 jumlah pengembunan lebih banyak dibandingkan zona 2. Disamping itu selisih suhu pengembun dengan udara pada zona 3 lebih kecil sehingga perpindahan panas juga semakin kecil hal ini sesuai dengan hukum newton berkaitan perpindahan panas konveksi

$$
q=h . A\left(T_{u}-T_{d}\right) \ldots \ldots \ldots \ldots \ldots
$$

Dengan: $\mathrm{q}=$ fluks panas

$\mathrm{h}=$ Koefisien perpindahan panas konveksi

$\mathrm{A}=$ Luas perpindahan panas

$\mathrm{Tu}=$ Suhu udara

$\mathrm{Td}=$ Suhu dinding

Zona pengembunan 4 seperti pada zona 1 dengan arah miring dan memiliki arus searah antara asap dan embunan, pada zona ini luas perpindahan panasnya $358,14 \mathrm{~cm}^{2}$ dengan kisaran suhu $100{ }^{\circ} \mathrm{C}$ sampai $79{ }^{\circ} \mathrm{C}$ penurunan suhu yang terjadi adalah $21{ }^{\circ} \mathrm{C}$. Fenomena yang terjadi pada zoan ini sama dengan zona 1 , apabila dibandingkan dengan zona 1 maka penurunan suhu tiap satuan luasnya adalah $0,059{ }^{\circ} \mathrm{C} / \mathrm{cm}^{2}$ untuk zona 1 dan $0,057{ }^{\circ} \mathrm{C} / \mathrm{cm}^{2}$ untuk zona 4 , perbedaan ini disebabkan perbedaan suhu dengan suhu udara yang lebih kecil dibandingkan zona 1 .

Zona pengembunan 5 berupa pengembun tegak dengan luas permukaan 1969,78 dengan kisaran suhu 79 sampai 54, pada zona ini penurunan suhu tiap luas perpindahan panas adalah $0,013{ }^{0} \mathrm{C} / \mathrm{cm}^{2}$ angka ini menunjukkan bahwa pada zona ini panas yang diambil adalah panas pengembunan dibandingkan panas penurun suhu, penyebab lain kecilnya angka penurunan suhu tiap luas muka juga disebabkan harga perbedaan suhu dalam pengembun dengan udara semakin kecil sehingga fluks panas juga semakin kecil.

Jumlah embunan yang diperoleh dari penampung pengembun 1, 2 dan 3 dapat dilihat dalam gambar 3. Data gambar 3 menunjukkan embunan yang ditampung pada pengembun 1 adalah hasil pengembunan zona 1, zona 2 dan zona 3 dengan titik embun diatas $100{ }^{\circ} \mathrm{C}$ memiliki volume yang terkecil yaitu hanya $22 \mathrm{ml}$, dan dari segi bentuk maka embunan pada penampung embunan 1 berupa tar yang kental. Hasil embunan pada penampung embunan 2 adalah hasil dari embunan zona 4 dan zona 5 dengan kisaran titik didih antara $100{ }^{\circ} \mathrm{C}$ sampai 54 ${ }^{0} \mathrm{C}$ jumlah embunan pada penampung ini paling banyak yaitu $197 \mathrm{ml}$, embunan pada fase ini berupa cairan encer dengan warna yang masih hitam dan keruh. Hasil embunan pada penampung embunan 3 adalah komponen yang tidak mengembun di zona 1 sampai 5, embunan pada penampung 3 berjumlah $143 \mathrm{ml}$ dengan penampakan fisik encer dengan warna lebih terang dibanding embunan pada penampung 2 dan lebih jernih.

\section{Kesimpulan}

1. Pengembunan asap hasil pengarangan kelapa dapat dilakukan dengan pengembunan parsial bertingkat.

2. Dengan pengaturan suhu tiap zona pengembunan dapat dipisahkan embunan tar pada suhu diatas $100{ }^{\circ} \mathrm{C}$ dan embunan asap cair pada suhu dibawahnya.

3. Warna embunan yang diperoleh semakin rendah suhu semakin terang dan jernih.

4. Pada pengembun tegak dan diameter kecil dapat diembunkan embunan sesuai kisaran titik didih alat.

\section{Daftar Pustaka}

[1] --- ，2006, Pedoman Efisiensi Energi untuk Industri -www.energyefficiencyasia.org

[2] Jamilatun, S., dan Setyawan, M., 2012. Kondensasi Asap Pirolisis Tempurung Kelapa Menjadi Asap Cair (Liquid Smoke) Berbasis pada Luas Transfer Perpindahan Panas, Proceedings The First Symphosium in Industrial Technology.

[3] Smith, J.W., and Timmermans, F.A. 1982, Liquid Smoke Concentrate, U.S. Patent

[4] Weber, M. 1988, Heat Transfer in a single Vertical Tube Condensor Sub Cooler, Experimental and Theoritical Study, Universite de lige.

[5] Setyawan, M., 2014, Optimasi Alat Pengembun Asap Cair sebagai Pemanfaatan Limbah Pembuatan Arang Tempurung Kelapa Skala Industri Mikro, Laporan Penelitian, Universitas Ahmad Dahlan. 